\title{
Evaluasi Penggunaan Energi Listrik Pada Terminal Bus Tipe A Antar Lintas Batas Negara (ALBN) Sei. Ambawang
}

\author{
Tabita Dwilova Wijayanti \\ Magister Teknik Elektro Universitas Tanjungpura Pontianak, \\ PPNPN Kementerian Perhubungan Direktorat Jenderal Perhubungan Darat Area Terminal \\ Tipe A Antar Lintas Batas Negara Sei. Ambawang. \\ e-mail : tabitadwilovawijayanti@gmail.com
}

\begin{abstract}
Evaluasi Intensitas Konsumsi Energi listrik merupakan suatu usaha untuk mengidentifikasikan jenis dan besaran energi yang digunakan pada bagian-bagian operasional suatu bangunan.Kriteria penggunaan energi listrik ditentukan berdasarkan pada nilai IKE pada gedung yaitu sangat efisien, efisien, cukup efisien atau boros dan mencoba untuk mengidentifikasi karakteristik penggunaan energi listrik serta mengidentifikasi kemungkinan peluang hemat energi.Demikian halnya dengan Terminal Tipe A Antar Lintas Batas Negara Sei. Ambawang.

Hasil perhitungan IKE pada Terminal Bus Tipe A Antar Lintas Batas Negara Sei. Ambawang dibandingkan dengan standar IKE bahwa penggunaan energi listrik masih belum melewati standar IKE. Evaluasi nilai IKE yang diperoleh pada seluruh gedung yaitu 6,88 $\mathrm{kWh} / \mathrm{m}^{2} /$ tahun dan pada nilai IKE tanpa lantai III 7,55 $\mathrm{kWh} / \mathrm{m}^{2} /$ tahun. Pada lantai I nilai IKE 6,30 $\mathrm{kWh} / \mathrm{m}^{2} /$ tahun dan pada lantai II $16,7 \mathrm{kWh} / \mathrm{m}^{2} /$ tahun. Hasil nilai IKE pada lantai I untuk ruang ber-AC adalah 195,4 $\mathrm{kWh} / \mathrm{m}^{2} /$ tahun dan pada ruang tidak ber-AC adalah $0,08 \mathrm{kWh} / \mathrm{m}^{2} /$ tahun sedangkan nilai IKE pada lantai II untuk ruang ber-AC adalah 26,84 $\mathrm{kWh} / \mathrm{m}^{2} /$ tahun dan pada ruang tidak ber-AC adalah 1,39 $\mathrm{kWh} / \mathrm{m}^{2} /$ tahun.

Hal ini menunjukan bahwa masih bisa dilakukan peluang hemat energi di Terminal Bus Tipe A Antar Lintas Batas Negara Sei. Ambawang pada penggunaan $A C$ dengan melakukan pengaturan suhu AC dan penjadwalan pengoperasian AC.
\end{abstract}

Keywords- Evaluasi, Intensitas Konsumsi Energi, Peluang hemat Energi

\section{Pendahuluan}

Bangunan gedung merupakan bagian dari usaha yang ada di Indonesia mengalami perkembangan dari tahun ke tahun. Seiring dengan jumlah bangunan gedung yang bertambah, kebutuhan energi tersebut perlu diikuti dengan manajemen energi sebagai langkah aktif penghematan konsumsi energi listrik dan mendukung kebijakan pemerintah dalam melaksanakan manajemen energi secara optimal.

Salah satu upaya yang bisa dilakukan untuk menanggulangi krisis listrik di Indonesia adalah dengan jalan melakukan penghematan-penghematan listrik disegala bidang kegiatan yang menggunakan listrik. Energi sangat penting, terutama dalam pemakaian energi listrik pada setiap bangunan sebaiknya sudah harus dipikirkan sejak awal perencanaan. Termasuk dalam pemilihan jenis lampu penerangan yang akan digunakan dan penggunaan air conditioner (AC) yang mempengaruhi pengaturan operasinya, sehingga biaya energi listrik dapat ditekan seminimal mungkin. Konservasi energi adalah proses yang digunakan untuk melakukan penghematan energi. Proses ini meliputi adanya evaluasi penggunaan energi yaitu metode untuk menghitung tingkat konsumsi energi listrik pada suatu bangunan gedung. Adanya peraturan yang ditetapkan oleh Presiden untuk melakukan penghematan energi berdampak pula pada bangunan gedung pemerintah yang mengharuskan penghematan energi sesuai dengan peraturan menteri ESDM No. 13 tahun 2012 tentang penghematan pemakaian listrik.

Demikian halnya dengan Terminal Bus Tipe A Antar Lintas Batas Negara (ALBN) Sei Ambawang yang masih termasuk kedalam bangunan gedung pemerintah. Terminal Bus Tipe A ALBN Sei Ambawang dalam pengoperasinya menggunakan energi listrik yaitu pemakaian penerangan (lampu), air conditioner (AC) dan beban lain-lain. Dari hasil observasi awal yang penulis lakukan sejak Terminal Bus Tipe A ALBN Sei Ambawang beroperasi selama empat tahun, pada tahun 2013, proses evaluasi penggunaan energi listrik belum pernah dilakukan. Saat ini dirasakan oleh bagian keuangan bahwa pembayaran rekening listrik masih relatif mahal. Selain itu perlu dievaluasi penggunaan energinya karena sering terjadi fluktuasi pembayaran sesuai dengan rekening listrik.

Tabel 1. Pembayaran Rekening Per Bulan

\begin{tabular}{ccccc}
\hline $\begin{array}{c}\text { BULAN / } \\
\text { TAHUN }\end{array}$ & STAND METER & $\begin{array}{c}\text { TOTAL } \\
\text { kWh }\end{array}$ & ENERGI COST \\
\hline Jan-16 & 3.780 & 3.950 & 6.816 & 10.293 .934 \\
Feb-16 & 3.950 & 4.137 & 7.489 & 10.559 .199 \\
Mar-16 & 4.137 & 4.319 & 7.274 & 10.132 .281 \\
Apr-16 & 4.319 & 4.545 & 9.029 & 12.242 .913 \\
Mei-16 & 4.545 & 4.757 & 8.487 & 11.403 .871 \\
Jun-16 & 4.757 & 4.970 & 8.525 & 11.544 .161 \\
Jul-16 & 4.970 & 5.178 & 8.331 & 11.376 .649 \\
Agust-16 & 5.178 & 5.376 & 7.912 & 11.182 .966 \\
Sep-16 & 5.376 & 5.583 & 8.279 & 11.680 .383 \\
Okt-16 & 5.583 & 5.785 & 8.069 & 11.768 .343 \\
Nov-16 & 5.785 & 5.991 & 8.240 & 12.034 .258 \\
Des-16 & 5.991 & 6.177 & 7.437 & 10.877 .407 \\
& Total & & $\mathbf{9 5 . 8 8 8}$ & $\mathbf{1 3 5 . 0 9 6 . 3 6 5}$ \\
& Rata-rata & & $\mathbf{7 . 9 9 1}$ & $\mathbf{1 1 . 2 5 8 . 0 3 0}$ \\
\hline
\end{tabular}

Sumber : Terminal Bus Tipe A ALBN 2016 


\section{Tinjauan Pustaka}

\subsection{Manejemen Energi}

Manajemen energi merupakan kegiatan yang di lakukan guna mengelola pemakaian energi listrik, sehingga adanya penghematan dalam menggunakan energi listrik, dengan demikian terjadi minimalisasi konsumsi energi listrik dapat lebih efektif dan efisien bagi organisasi kantor.

Sedangkan Shalahudin, Hasan (2014) menyatakan manajemen energiadalah: Kegiatan disuatu perusahaan yang terorganisir dengan menggunakan prinsip-prinsip manajemen, dengan tujuan agar dapat ditekan serendahrendahnya.

\subsection{Intensitas Konsumsi Energi}

Intensitas Konsumsi Energi (IKE), merupakan pembagian antara penggunaan sumber daya energi dengan luas bangunan gedung perkantoran. sejalan pendapat Sulistyorini (2012) mengatakan intensitas konsumsi energi adalah: "pembagian antara konsumsi energi dengan satuan luas bangunan gedung".

Berdasarkan SNI 03-6196-2000 tentang prosedur audit energi bangunan gedung intensitas konsumsi energi pada setiap ruangan dapat dihitung dengan menggunakan persamaan berikut: Berdasarkan SNI 03-6196-2000 tentang prosedur audit energi bangunan gedung intensitas konsumsi energi pada setiap ruangan dapat dihitung dengan menggunakan persamaan berikut:

$$
I K E=\frac{E_{K}}{\mathrm{~A}}
$$

dengan:

IKE = Intensitas Konsumsi Energi $\left(\mathrm{kWh} / \mathrm{m}^{2} /\right.$ tahun $)$

$E_{\mathrm{k}}=$ Konsumsi listrik total (kWh/tahun)

$\mathrm{A}=$ Luas area $\left(\mathrm{m}^{2}\right)$

\section{Data Objektif Penelitian \\ 3.1 Tempat Penelitian}

Penelitian Ini dilakukan di Terminal Bus Tipe A Antar Lintas Batas Negara yang beralamat Jl. Trans Kalimantan Sungai Ambawang Kuala. Sungai Ambawang Kabupaten Kubu Raya Kalimantan Barat.

Kebutuhan listrik Terminal Antar lintas Batas Negara disuplai dari jaringan distribusi PLN dengan tarif / daya P1 yaitu sebagai pelanggan untuk kantor pemerintah. Kapasitas daya terpasang 105000 VA dan luas area $13.554,22 \mathrm{~m}^{2}$.

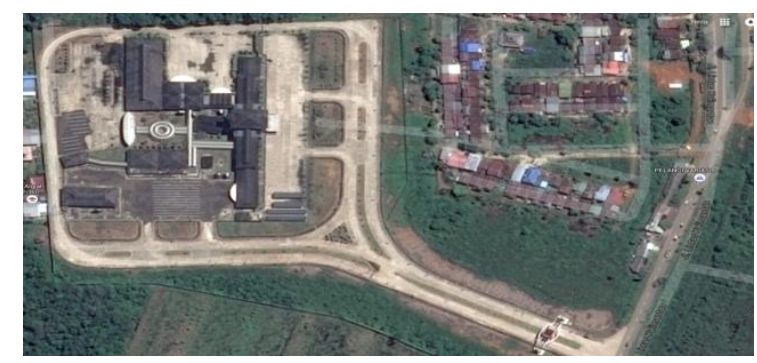

\subsection{Diagaram Alir Penelitian}

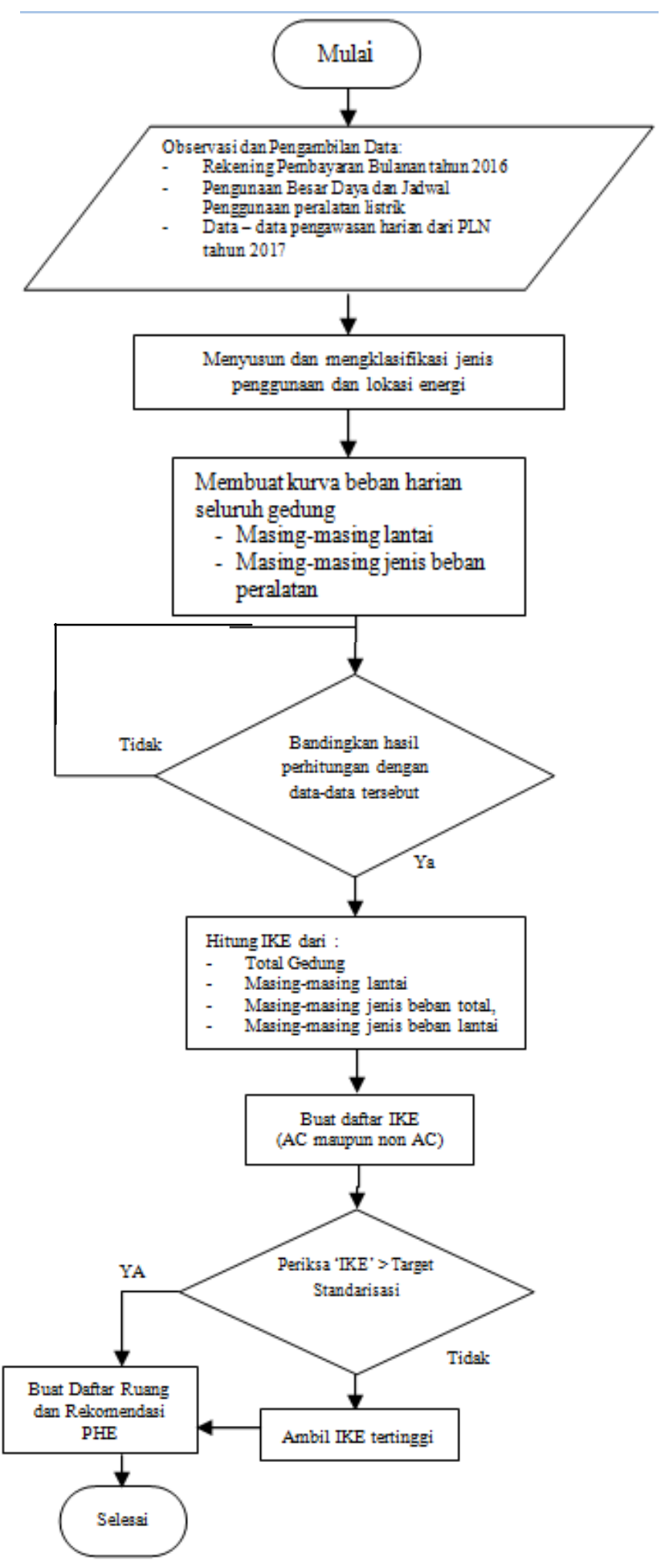

4. Pengolahan Data dan Analisa Hasil

4.1 Karakteristik Penggunaan Energi Listrik Seluruh Gedung

Data yang diperoleh dari PT.PLN yaitu hasil rekaman Automatic Meter Reading (AMR) selama satu hari, dimana rekaman $A M R$ tersebut berisi laporan pemakaian energi yang meliputi load profile energi, load profile arus. Berikut ditampilkan hasil rekaman $A M R$ pada tanggal 18 September 2017. 
Tabel 2. Hasil Pengukuran Arus di Terminal Bus Tipe A Antar Lintas Batas Negara Sei. Ambawang

Pada Tanggal 18 September 2017

\begin{tabular}{cccccccc}
\hline No. & Tanggal & Jam & $\begin{array}{c}\text { Ampere } \\
\text { R }\end{array}$ & $\begin{array}{c}\text { Ampere } \\
\text { S }\end{array}$ & $\begin{array}{c}\text { Ampere } \\
\text { T }\end{array}$ & KW & $\begin{array}{c}\text { KWH } \\
\text { Kirim }\end{array}$ \\
\hline $\mathbf{l}$. & $18 / 09 / 2017$ & 00.00 & 1,002 & 0,408 & 0,227 & 1,448 & 0,362 \\
$\mathbf{2 .}$ & & 01.00 & 0,979 & 0,342 & 0,223 & 1,356 & 0,339 \\
$\mathbf{3 .}$ & & 02.00 & 0,986 & 0,344 & 0,243 & 1,376 & 0,344 \\
$\mathbf{4 .}$ & & 03.00 & 0,968 & 0,341 & 0,237 & 1,360 & 0,340 \\
$\mathbf{5 .}$ & & 04.00 & 0,967 & 0,339 & 0,222 & 1,352 & 0,338 \\
$\mathbf{6 .}$ & & 05.00 & 0,934 & 0,341 & 0,215 & 1,312 & 0,328 \\
$\mathbf{7 .}$ & & 06.00 & 0,828 & 0,307 & 0,225 & 1,176 & 0,294 \\
$\mathbf{8 .}$ & & 07.00 & 0,566 & 0,212 & 0,296 & 0,916 & 0,229 \\
\hline
\end{tabular}

Tabel 2. Hasil Pengukuran Arus di Terminal Bus Tipe A Antar Lintas Batas Negara Sei. Ambawang

Pada Tanggal 18 September 2017 (Lanjutan)

\begin{tabular}{cccccccc}
\hline No. & Tanggal & Jam & $\begin{array}{c}\text { Ampere } \\
\text { R }\end{array}$ & $\begin{array}{c}\text { Ampere } \\
\text { S }\end{array}$ & $\begin{array}{c}\text { Ampere } \\
\text { T }\end{array}$ & KW & $\begin{array}{c}\text { KWH } \\
\text { Kirim }\end{array}$ \\
\hline $\mathbf{9 .}$ & $18 / 09 / 2017$ & 08.00 & 0,300 & 0,222 & 0,280 & 0,712 & 0,178 \\
$\mathbf{1 0 .}$ & & 09.00 & 0,379 & 0,250 & 0,176 & 0,716 & 0,179 \\
$\mathbf{1 1 .}$ & & 10.00 & 0,591 & 0,247 & 0,389 & 1,104 & 0,276 \\
$\mathbf{1 2 .}$ & & 11.00 & 0,642 & 0,403 & 0,606 & 1,360 & 0,340 \\
$\mathbf{1 3 .}$ & & 12.00 & 0,725 & 0,506 & 0,698 & 1,644 & 0,411 \\
$\mathbf{1 4}$ & & 13.00 & 0,780 & 0,638 & 0,740 & 1,824 & 0,456 \\
$\mathbf{1 5 .}$ & & 14.00 & 1,000 & 0,654 & 0,781 & 2,152 & 0,538 \\
$\mathbf{1 6 .}$ & 15.00 & 0,896 & 0,665 & 0,905 & 2,176 & 0,544 \\
$\mathbf{1 7 .}$ & & 16.00 & 0,950 & 0,511 & 0,947 & 2,280 & 0,570 \\
$\mathbf{1 8 .}$ & & 17.00 & 0,777 & 0,637 & 0,659 & 1,632 & 0,408 \\
$\mathbf{1 9 .}$ & 18.00 & 1,156 & 0,715 & 0,724 & 2,256 & 0,564 \\
$\mathbf{2 0 .}$ & & 19.00 & 1,469 & 0,600 & 0,727 & 2,588 & 0,647 \\
$\mathbf{2 1 .}$ & 20.00 & 1,261 & 0,506 & 0,665 & 2,232 & 0,558 \\
$\mathbf{2 2 .}$ & 21.00 & 1,213 & 0,614 & 0,679 & 2,120 & 0,530 \\
$\mathbf{2 3 .}$ & 22.00 & 1,181 & 0,619 & 0,408 & 1,936 & 0,484 \\
$\mathbf{2 4 .}$ & & 23.00 & 1,144 & 0,534 & 0,408 & 1,908 & 0,477 \\
\hline
\end{tabular}

Jenis $A C$ yang digunakan untuk masing-masing ruangan di Terminal Tipe A Antar Lintas Batas Negara ini dapat dilihat pada tabel 3

Tabel 3 Pemakaian AC

\begin{tabular}{|c|c|c|c|c|c|c|}
\hline Lantai & $\begin{array}{l}\text { Nama } \\
\text { Ruang }\end{array}$ & Model AC & $\begin{array}{c}\text { Jumlah } \\
\text { (Unit) }\end{array}$ & $\begin{array}{c}\text { Daya } \\
\text { (Watt) }\end{array}$ & Jam Nyala & $\begin{array}{c}\text { Total } \\
\text { Konsumsi } \\
\text { (kWH) }\end{array}$ \\
\hline 1 & $\begin{array}{l}\text { Ruang Loket } \\
\text { Penjualan } \\
\text { Tiket Bus } \\
\text { ALBN B }\end{array}$ & AC Split 1 PK & 5 & 746 & $\begin{array}{l}06.00-08.00 \\
17.00-21.00\end{array}$ & 22,38 \\
\hline 1 & $\begin{array}{l}\text { Ruang } \\
\text { Teknisi }\end{array}$ & AC Split 1 PK & 1 & 746 & 24 & 17,90 \\
\hline 1 & $\begin{array}{l}\text { Ruang } \\
\text { Informasi }\end{array}$ & AC Split 1 PK & 1 & 746 & 24 & 17,90 \\
\hline 1 & $\begin{array}{l}\text { Ruang } \\
\text { Retribusi }\end{array}$ & AC Split 2 PK & 1 & 1.496 & 24 & 35,90 \\
\hline 2 & $\begin{array}{l}\text { Ruang } \\
\text { Administrasi }\end{array}$ & AC Split 2 PK & 1 & 1.496 & $08.00-16.00$ & 11,96 \\
\hline 2 & $\begin{array}{l}\text { Ruang } \\
\text { CCTV }\end{array}$ & $\begin{array}{lll}\text { AC } & \text { Split } & 1,5 \\
\text { PK } & & \end{array}$ & 1 & 1.119 & 24 & 26,85 \\
\hline 2 & $\begin{array}{l}\text { Ruang } \\
\text { Koordinator } \\
\text { Terminal }\end{array}$ & AC Split 2 PK & 1 & 1.496 & $08.00-16.00$ & 11.96 \\
\hline & Total & seluruhan & 11 & 7.845 watt & & $85 \mathrm{kWh} / \mathrm{Hari}$ \\
\hline
\end{tabular}

Konsumsi energi listrik pada sistem pencahayaan di Terminal Tipe A Antar Lintas Batas Negara dipengaruhi oleh jumlah lampu, daya lampu dan lama waktu pengoperasiannya. Jumlah lampu dapat dilihat pada tabel 4

Tabel 4 Konsumsi Energi Listrik Pada Sistem Pencahayaan

\begin{tabular}{|c|c|c|c|c|c|c|}
\hline Lantai & $\begin{array}{l}\text { Nama } \\
\text { Ruang }\end{array}$ & Tipe Lampu & $\begin{array}{c}\text { Jumlah } \\
\text { (Unit) }\end{array}$ & $\begin{array}{l}\text { Daya } \\
\text { (Watt) }\end{array}$ & Jam Nyala & $\begin{array}{c}\text { Total } \\
\text { Konsumsi } \\
\text { (kWh) }\end{array}$ \\
\hline l & Informasi & Lampu DP PL-C & 1 & 23 & $18.00-06.00$ & 0,253 \\
\hline 1 & & Lampu TLD Bedhead & 1 & 10 & $18.00-06.00$ & 0,110 \\
\hline 1 & Teknisi & Lampu DP PL -C & 1 & 11 & $18.00-06.00$ & 0,121 \\
\hline 1 & $\begin{array}{l}\text { Loket } \\
\text { Tiket } \\
\text { ALBN }\end{array}$ & Lampu DP PL -C & 6 & 18 & $17.00-21.00$ & 0,432 \\
\hline 1 & & Lampu TLD Bedhead & 2 & 10 & $18.00-06.00$ & 0,220 \\
\hline 1 & Retribusi & Lampu DP PL -C & 4 & 11 & $18.00-06.00$ & 0,484 \\
\hline 1 & Kantin & Lampu DP PL-C & 8 & 18 & $17.00-21.00$ & 0,576 \\
\hline 1 & $\begin{array}{l}\text { Selasar } \\
\text { Gedung } \\
\text { Utama }\end{array}$ & Lampu DP PL -C & 11 & 18 & $18.00-06.00$ & 2,178 \\
\hline
\end{tabular}

Sedangkan konsumsi untuk peralatan listrik pada Terminal Tipe A Antar Lintas Batas Negara dapat dilihat pada tabel 5

Tabel 5 Konsumsi Energi Listrik Pada Peralatan Listrik

\begin{tabular}{|c|c|c|c|c|c|c|}
\hline Lantai & Peralatan Listrik & $\begin{array}{l}\text { Jumlah } \\
\text { (Unit) }\end{array}$ & $\begin{array}{r}\text { Daya } \\
\text { (Watt) }\end{array}$ & & Jam Nyala & $\begin{array}{l}\text { Total Konsumsi } \\
(\mathrm{kWh})\end{array}$ \\
\hline 1 & Komputer & 4 & 140 & $\begin{array}{l}\text { a. } \\
\text { b. }\end{array}$ & $\begin{array}{l}06.00-08.00 \\
17.00-21.00\end{array}$ & 3,36 \\
\hline 1 & Printer & 4 & 20 & $\begin{array}{l}\text { a. } \\
\text { b. }\end{array}$ & $\begin{array}{l}06.00-08.00 \\
17.00-21.00\end{array}$ & 0,48 \\
\hline 1 & LED TV $32^{\prime \prime}$ & 1 & 120 & & 24 & 2,88 \\
\hline 1 & LED TV $29^{\prime \prime}$ & 1 & 70 & & $14.00-21.00$ & 0,42 \\
\hline 1 & LED TV 14" & 2 & 45 & & $12.00-18.00$ & 0,54 \\
\hline 1 & Kulkas & 3 & 74 & & $08.00-21.00$ & 2,88 \\
\hline 1 & Showcase & 5 & 180 & & $08.00-21.00$ & 25.920 \\
\hline 1 & Kipas Angin & 2 & 37 & & $11.00-21.00$ & 0,74 \\
\hline 1 & Kipas Angin Berdiri & 1 & 45 & & $11.00-21.00$ & 0,45 \\
\hline 1 & Dispenser & 3 & 350 & & $08.00-21.00$ & 13,65 \\
\hline 1 & Pompa Air & 3 & 650 & & $10.00-14.00$ & 7,80 \\
\hline 2 & Komputer & 2 & 140 & & $08.00-16.00$ & 2,24 \\
\hline
\end{tabular}

Dari observasi dan pengukuran data penggunaan beban AC pada tabel 3, beban penerangan pada tabel 4, serta beban lain-lain pada tabel 5, dapat dibuat karakteristik penggunaan beban listrik total seluruh gedung seperti pada tabel 6 berikut :

Tabel 6. Beban Seluruh Gedung

\begin{tabular}{lcccc}
\hline Waktu & \multicolumn{4}{c}{ Beban (Watt) } \\
\cline { 2 - 5 } $\mathbf{0 0}$ & Penerangan & AC & Lain-1ain & Gabungan \\
$\mathbf{0 1}$ & 5362 & 4107 & 260 & 9729 \\
$\mathbf{0 2}$ & 5362 & 4107 & 260 & 9729 \\
$\mathbf{0 3}$ & 5362 & 4107 & 260 & 9729 \\
$\mathbf{0 4}$ & 5362 & 4107 & 260 & 9729 \\
$\mathbf{0 5}$ & 5362 & 4107 & 260 & 9729 \\
$\mathbf{0 6}$ & 5362 & 4107 & 260 & 9729 \\
$\mathbf{0 7}$ & 36 & 7837 & 260 & 9729 \\
$\mathbf{0 8}$ & 36 & 7837 & 820 & 8693 \\
$\mathbf{0 9}$ & 36 & 7099 & 820 & 8693 \\
$\mathbf{1 0}$ & 36 & 7099 & 3342 & 10477 \\
$\mathbf{1 1}$ & 36 & 7099 & 5032 & 10477 \\
$\mathbf{1 2}$ & 36 & 7099 & 5151 & 12167 \\
$\mathbf{1 3}$ & 36 & 7099 & 5241 & 12286 \\
$\mathbf{1 4}$ & 36 & 7099 & 5241 & 12376 \\
$\mathbf{1 5}$ & 36 & 7099 & 3361 & 12376 \\
$\mathbf{1 6}$ & 36 & 7099 & 3361 & 10496 \\
$\mathbf{1 7}$ & 36 & 4107 & 2451 & 6596 \\
$\mathbf{1 8}$ & 288 & 7837 & 3011 & 11136 \\
$\mathbf{1 9}$ & 5614 & 7837 & 2921 & 16372 \\
$\mathbf{2 0}$ & 5614 & 7837 & 2921 & 16372 \\
$\mathbf{2 1}$ & 5614 & 4107 & 2921 & 12652 \\
$\mathbf{2 2}$ & 5362 & 4107 & 260 & 9739 \\
$\mathbf{2 3}$ & 5362 & 4107 & 260 & 9739 \\
\hline
\end{tabular}

Dari tabel 6 dapat dihitung penggunaan energi listrik per-hari sebesar 259,224 kWh atau sekitar 7.776,72 $\mathrm{kWh}$ per-bulannya. Data ini jika dibandingkan dengan data rekening pembayaran per-bulan (tabel 1) yang rataratanya sebesar $7.991 \mathrm{kWh}$ menunjukkan perkiraan observasi data pemakaian masing-masing beban sudah sangat mendekati. Dari data diatas juga dapat diketahui beban total berkisar antara 9.729 watt (minimum) hingga 16.372 watt (maksimum), dengan harga beban rata-rata sebesar 10.801 watt atau 10,8 Kw. Jika faktor bebannya dihitung sebagai perbandingan antara beban rata-rata terhadap beban maksimum diperoleh sebesar 0,66. Faktor beban ini digunakan untuk melihat fluktuasi naik turunnya penggunaan beban listrik. Dari Tabel 6 dapat juga dihitung penggunaan energi listrik untuk masingmasing jenis klasifikasi beban yang digunakan. Hasil perhitungan dapat dilihat pada Tabel 7 berikut : 
Tabel 7. Hasil perhitungan Penggunaan energi listrik Masing-masing klasifikasi beban

\begin{tabular}{cccccc}
\hline $\begin{array}{c}\text { Klasifikasi } \\
\text { Beban }\end{array}$ & $\begin{array}{c}\text { Beban } \\
\text { Mini- } \\
\text { mum } \\
\text { (watt) }\end{array}$ & $\begin{array}{c}\text { Beban } \\
\text { Maxi- } \\
\text { mum } \\
\text { (watt) }\end{array}$ & $\begin{array}{c}\text { Beban } \\
\text { Rata- } \\
\text { rata } \\
\text { (watt) }\end{array}$ & $\begin{array}{c}\text { Penggunaan } \\
\text { Energi per- } \\
\text { hari (Kwh) }\end{array}$ & $\begin{array}{c}\text { Faktor } \\
\text { Beban }\end{array}$ \\
\hline AC & 4.107 & 7.837 & 5.881 & 141,154 & 0,75 \\
Penerangan & 36 & 5.614 & 2.741 & 65,784 & 0,49 \\
Lain-lain & 260 & 5.241 & 2.179 & 52,286 & 0,42 \\
Gabungan & 9.729 & 16.372 & 10.801 & 259,224 & 0,66 \\
\hline
\end{tabular}

Dari Tabel 7 diperoleh penggunaan listrik terbesar dari beban AC (sekitar 54\%) dari beban total gabungan, serta mempunyai beban cenderung kontinyu stabil besarnya yang terlihat dari besar faktor beban 0,75. Dari data ini peluang hemat energi dapat diarahkan kepengaturan atau penjadwalan beban AC.

\subsection{Karakteristik Penggunaan Energi Listrik Pada Masing-masing Lantai}

Dari observasi dan pengukuran data penggunaan beban pada tabel 3 , tabel 4 , serta tabel 5 juga dapat dibuat karakteristik penggunaan beban listrik untuk masing-masing lantai bangunan seperti pada tabel 8 berikut:

Tabel 8. Beban Listrik Per Lantai

\begin{tabular}{ccccc}
\hline Waktu & \multicolumn{4}{c}{ Beban (Watt) } \\
\cline { 2 - 5 } $\mathbf{0 0 . 0 0}$ & Lantai I & Lantai II & Lantai III & Total \\
$\mathbf{0 1 . 0 0}$ & 7974 & 1611 & 144 & 9729 \\
$\mathbf{0 2 . 0 0}$ & 7974 & 1611 & 144 & 9729 \\
$\mathbf{0 3 . 0 0}$ & 7974 & 1611 & 144 & 9729 \\
$\mathbf{0 4 . 0 0}$ & 7974 & 1611 & 144 & 9729 \\
$\mathbf{0 5 . 0 0}$ & 7974 & 1611 & 144 & 9729 \\
$\mathbf{0 6 . 0 0}$ & 7974 & 1611 & 144 & 9729 \\
$\mathbf{0 7 . 0 0}$ & 7398 & 1611 & 144 & 9729 \\
$\mathbf{0 8 . 0 0}$ & 7398 & 1295 & 0 & 8693 \\
$\mathbf{0 9 . 0 0}$ & 5280 & 1295 & 0 & 8693 \\
$\mathbf{1 0 . 0 0}$ & 5280 & 5197 & 0 & 10477 \\
$\mathbf{1 1 . 0 0}$ & 6970 & 5197 & 0 & 10477 \\
$\mathbf{1 2 . 0 0}$ & 7089 & 5197 & 0 & 12167 \\
$\mathbf{1 3 . 0 0}$ & 7179 & 5197 & 0 & 12286 \\
$\mathbf{1 4 . 0 0}$ & 7179 & 5197 & 0 & 12376 \\
$\mathbf{1 5 . 0 0}$ & 5299 & 5197 & 0 & 12376 \\
$\mathbf{1 6 . 0 0}$ & 5299 & 5197 & 0 & 10496 \\
$\mathbf{1 7 . 0 0}$ & 5299 & 1295 & 0 & 10496 \\
$\mathbf{1 8 . 0 0}$ & 9841 & 1295 & 0 & 6594 \\
$\mathbf{1 9 . 0 0}$ & 14617 & 1611 & 0 & 11136 \\
$\mathbf{2 0 . 0 0}$ & 14617 & 1611 & 144 & 16372 \\
$\mathbf{2 1 . 0 0}$ & 10897 & 1611 & 144 & 16372 \\
$\mathbf{2 2 . 0 0}$ & 7984 & 1611 & 144 & 12652 \\
$\mathbf{2 3 . 0 0}$ & 7984 & 1611 & 144 & 9739 \\
\hline & & 144 & 9739 \\
\hline
\end{tabular}

Seperti uraian diatas, dari Tabel 8dapat juga dihitung penggunaan energi listrik pada masing-masing lantai dari bangunan. Hasil perhitungan dapat dilihat pada Tabel 9 berikut :

Tabel 9. Hasil perhitungan Penggunaan energi listrik Pada Masing-masing Lantai Bangunan

\begin{tabular}{cccccc}
\hline $\begin{array}{c}\text { Lantai } \\
\text { Gedung }\end{array}$ & $\begin{array}{c}\text { Beban } \\
\text { Mini- } \\
\text { mum } \\
\text { (watt) }\end{array}$ & $\begin{array}{c}\text { Beban } \\
\text { Maxi- } \\
\text { mum } \\
\text { (watt) }\end{array}$ & $\begin{array}{c}\text { Beban } \\
\text { Rata- } \\
\text { rata } \\
\text { (watt) }\end{array}$ & $\begin{array}{c}\text { Penggunaan } \\
\text { Energi per- } \\
\text { hari (Kwh) }\end{array}$ & $\begin{array}{c}\text { Faktor } \\
\text { Beban }\end{array}$ \\
\hline I & 5.280 & 14.617 & 7.975 & 191,408 & 0,55 \\
II & 1.295 & 5.197 & 2.754 & 66,088 & 0,53 \\
III & 0 & 144 & 72 & 1,728 & 0,50 \\
Gabungan & 9.729 & 16.372 & 10.801 & 259,224 & 0,66 \\
\hline
\end{tabular}

Dari Tabel 9 diperoleh penggunaan listrik terbesar pada lantai I (sekitar 73,8\%) dari beban total gabungan. Beban pada Lantai II sekitar $25,5 \%$ serta beban pada lantai III hanya sekitar $0,7 \%$. Sedangkan faktor beban hampir sama yaitu berkisar dinilai 0,5. Ini memperlihatkan fluktuasi beban sudah mengikuti jam operasi perkantoran. Dari data ini peluang hemat energi dapat diarahkan ke-pengaturan atau penjadwalan beban pada lantai I.

\subsection{Karakteristik Penggunaan Energi Listrik Pada \\ Lantai I}

Dari observasi dan pengukuran data penggunaan beban pada tabel 3, tabel 4, serta tabel 5 juga dapat dibuat karakteristik penggunaan beban listrik untuk lantai I bangunan seperti pada tabel 10 berikut:

Tabel 10. Beban Listrik Lantai I

\begin{tabular}{lcccc}
\hline Waktu & \multicolumn{4}{c}{ Beban (Watt) } \\
\cline { 2 - 5 } & Penerangan & AC & $\begin{array}{c}\text { Lain- } \\
\text { lain }\end{array}$ & Total \\
$\mathbf{0 5 . 0 0}$ & 4866 & 2988 & 120 & 7974 \\
$\mathbf{0 6 . 0 0}$ & 4866 & 2988 & 120 & 7974 \\
$\mathbf{0 7 . 0 0}$ & 0 & 6718 & 680 & 7398 \\
$\mathbf{0 8 . 0 0}$ & 0 & 6718 & 680 & 7398 \\
$\mathbf{0 9 . 0 0}$ & 0 & 2988 & 2292 & 5280 \\
$\mathbf{1 0 . 0 0}$ & 0 & 2988 & 2292 & 5280 \\
$\mathbf{1 1 . 0 0}$ & 0 & 2988 & 3982 & 6970 \\
$\mathbf{1 2 . 0 0}$ & 0 & 2988 & 4101 & 7089 \\
$\mathbf{1 3 . 0 0}$ & 0 & 2988 & 4191 & 7179 \\
$\mathbf{1 4 . 0 0}$ & 0 & 2988 & 4191 & 7179 \\
$\mathbf{1 5 . 0 0}$ & 0 & 2988 & 2311 & 5299 \\
$\mathbf{1 6 . 0 0}$ & 0 & 2988 & 2311 & 5299 \\
$\mathbf{1 7 . 0 0}$ & 0 & 2988 & 2311 & 5299 \\
$\mathbf{1 8 . 0 0}$ & 252 & 6718 & 2871 & 9841 \\
$\mathbf{1 9 . 0 0}$ & 5118 & 6718 & 2781 & 14617 \\
$\mathbf{2 0 . 0 0}$ & 5118 & 6718 & 2781 & 14617 \\
$\mathbf{2 1 . 0 0}$ & 5118 & 2998 & 2781 & 10897 \\
$\mathbf{2 2 . 0 0}$ & 4866 & 2998 & 120 & 7984 \\
$\mathbf{2 3 . 0 0}$ & 4866 & 2998 & 120 & 7984 \\
\hline
\end{tabular}

Seperti uraian diatas, dari Tabel 10 dapat juga dihitung penggunaan energi listrik pada masing-masing lantai dari bangunan. Hasil perhitungan dapat dilihat pada Tabel 11 berikut :

Tabel 11. Hasil perhitungan Penggunaan energi listrik Lantai-I Masing-masing Klasifikasi Beban

\begin{tabular}{cccccc}
\hline $\begin{array}{c}\text { Klasifikasi } \\
\text { Beban }\end{array}$ & $\begin{array}{c}\text { Beban } \\
\text { Mini- } \\
\text { mum } \\
\text { (watt) }\end{array}$ & $\begin{array}{c}\text { Beban } \\
\text { Maxi- } \\
\text { mum } \\
\text { (watt) }\end{array}$ & $\begin{array}{c}\text { Beban } \\
\text { Rata- } \\
\text { rata } \\
\text { (watt) }\end{array}$ & $\begin{array}{c}\text { Penggunaan } \\
\text { Energi per- } \\
\text { hari (Kwh) }\end{array}$ & $\begin{array}{c}\text { Faktor } \\
\text { Beban }\end{array}$ \\
\hline AC & 2.988 & 6.718 & 3.765 & 90,362 & 0,56 \\
Penerangan & 0 & 5.118 & 2.475 & 59,400 & 0,48 \\
Lain-lain & 120 & 4.191 & 1.735 & 41,646 & 0,41 \\
Gabungan & 5.280 & 14.617 & 7.975 & 191,408 & 0,55 \\
\hline
\end{tabular}

Dari Tabel 11 pada Lantai I, penggunaan listrik terbesar masih pada penggunaan AC (sekitar 47,2\%) dari beban total gabungan. Selain itu faktor beban pun lebih besar dari faktor beban gabungan beban, berarti beban AC di lantai-I masih dikatakan kontinyu jam operasi pemakaiannya. Penjelasan lainnya dapat dilihat dari batasan beban minimumnya cukup besar dibandingkan yang lain.

\subsection{Karakteristik Penggunaan Energi Listrik Pada} Lantai II

Dari observasi dan pengukuran data penggunaan beban pada tabel 3, tabel 4, serta tabel 5 juga dapat dibuat karakteristik penggunaan beban listrik untuk lantai II bangunan seperti pada tabel 12 berikut: 
Tabel 12 Beban Listrik Lantai II

\begin{tabular}{ccccc}
\hline Waktu & \multicolumn{4}{c}{ Beban (Watt) } \\
\cline { 2 - 5 } & Penerangan & AC & Lain-lain & Total \\
$\mathbf{0 0 . 0 0}$ & 352 & 1119 & 140 & 1611 \\
$\mathbf{0 1 . 0 0}$ & 352 & 1119 & 140 & 1611 \\
$\mathbf{0 2 . 0 0}$ & 352 & 1119 & 140 & 1611 \\
$\mathbf{0 3 . 0 0}$ & 352 & 1119 & 140 & 1611 \\
$\mathbf{0 4 . 0 0}$ & 352 & 1119 & 140 & 1611 \\
$\mathbf{0 5 . 0 0}$ & 352 & 1119 & 140 & 1611 \\
$\mathbf{0 6 . 0 0}$ & 352 & 1119 & 140 & 1611 \\
$\mathbf{0 7 . 0 0}$ & 36 & 1119 & 140 & 1295 \\
$\mathbf{0 8 . 0 0}$ & 36 & 1119 & 140 & 1295 \\
$\mathbf{0 9 . 0 0}$ & 36 & 4111 & 1050 & 5197 \\
$\mathbf{1 0 . 0 0}$ & 36 & 4111 & 1050 & 5197 \\
$\mathbf{1 1 . 0 0}$ & 36 & 4111 & 1050 & 5197 \\
$\mathbf{1 2 . 0 0}$ & 36 & 4111 & 1050 & 5197 \\
$\mathbf{1 3 . 0 0}$ & 36 & 4111 & 1050 & 5197 \\
$\mathbf{1 4 . 0 0}$ & 36 & 4111 & 1050 & 5197 \\
$\mathbf{1 5 . 0 0}$ & 36 & 4111 & 1050 & 5197 \\
$\mathbf{1 6 . 0 0}$ & 36 & 4111 & 1050 & 5197 \\
$\mathbf{1 7 . 0 0}$ & 36 & 1119 & 140 & 1295 \\
$\mathbf{1 8 . 0 0}$ & 36 & 1119 & 140 & 1295 \\
$\mathbf{1 9 . 0 0}$ & 352 & 1119 & 140 & 1611 \\
$\mathbf{2 0 . 0 0}$ & 352 & 1119 & 140 & 1611 \\
$\mathbf{2 1 . 0 0}$ & 352 & 1119 & 140 & 1611 \\
$\mathbf{2 2 . 0 0}$ & 352 & 1119 & 140 & 1611 \\
$\mathbf{2 3 . 0 0}$ & 352 & 1119 & 140 & 1611 \\
\hline
\end{tabular}

Seperti uraian diatas, dari Tabel 12 dapat juga dihitung penggunaan energi listrik pada masing-masing lantai dari bangunan. Hasil perhitungan dapat dilihat pada Tabel 13 berikut :

Tabel 13. Hasil perhitungan Penggunaan energi listrik Lantai-II Masing-masing Klasifikasi Beban

\begin{tabular}{cccccc}
\hline $\begin{array}{c}\text { Klasifikasi } \\
\text { Beban }\end{array}$ & $\begin{array}{c}\text { Beban } \\
\text { Mini- } \\
\text { mum } \\
\text { (watt) }\end{array}$ & $\begin{array}{c}\text { Beban } \\
\text { Maxi- } \\
\text { mum } \\
\text { (watt) }\end{array}$ & $\begin{array}{c}\text { Beban } \\
\text { Rata-rata } \\
\text { (watt) }\end{array}$ & $\begin{array}{c}\text { Pengguna } \\
\text { an Energi } \\
\text { per-hari } \\
\text { (Kwh) }\end{array}$ & $\begin{array}{c}\text { Faktor } \\
\text { Beban }\end{array}$ \\
\hline AC & 1.119 & 4.111 & 2.116 & 50,792 & 0,51 \\
Penerangan & 36 & 352 & 194 & 4,656 & 0,55 \\
Lain-lain & 140 & 1.050 & 444 & 10,640 & 0,42 \\
Gabungan & 1.295 & 5.197 & 2.754 & 66,088 & 0,53 \\
\hline
\end{tabular}

Dari Tabel 13 pada Lantai II, penggunaan listrik terbesar juga pada penggunaan AC (sekitar 76,9\%) dari beban total gabungan. Selain itu beban pun masih bisa dikatakan merata, berarti beban AC di lantai-II masih dikatakan kontinyu jam operasi pemakaiannya. Penjelasan lainnya dapat dilihat dari batasan beban minimumnya cukup besar dibandingkan yang lain.

Karakteristik penggunaan energi listrik pada lantai III tidak dilakukan perhitungan karena pada lantai III tidak ada aktifitas hanya berupa lorong menuju ke arah menara.

\subsection{Peluang Hemat Energi dan Rekomendasi}

Berdasarkan analisis beban penggunaan energi listrik maka peluang hemat energi yang diperoleh bahwa lantai I lebih dominan dibandingkan pada lantai II dan klasifikasi penggunaan beban AC pada Terminal Tipe A Antar Lintas Batas Negara Sei. Ambawang lebih potensial.

Terminal Bus Tipe A Antar Lintas Batas Negara Sei. Ambawang belum melewati batas standar IKE, pada saat dilaksanakan penelitian ini sebagian besar ruangan di Terminal Bus Tipe A Antar Lintas Batas Negara Sei. Ambawang penggunaan AC belum banyak dioperasikan, sehingga hasil dari penelitian ini yang diperoleh bahwa Terminal Bus Tipe A Antar Lintas Batas Negara Sei. Ambawang masih termasuk kategori efisien. Tetapi pada saat sekarang pembayaran rekening listrik semakin meninggkat, diperoleh dari pembayaran rekening listrik bulan november 2017 sebesar Rp. 18.370.346 dengan konsumsi energi sebesar $8.534 \mathrm{kWh}$ dan pada bulan desember 2017 sebesar Rp 18.722.493 dengan konsumsi energi sebesar $8.853 \mathrm{kWh}$.

Hal ini dikarenakan Terminal Bus Tipe A Antar Lintas Batas Negara Sei. Ambawang baru selesai renovasi, ada beberapa tambahan ruangan yang menggunakan AC, penambahan lampu penerangan dibeberapa ruangan, penggunaan lampu hias dibagian gerbang masuk terminal, lampu hias dibagian halaman terminal, penambahan lampu penerangan tempat parkir motor, penambahan lampu sorot gedung, penambahan lampu penerangan pada papan petunjuk arah di Terminal Bus Tipe A Antar Lintas Batas Negara Sei. Ambawang. Selain itu dari hasil observasi yang ditemukan, pada pagi hari ada beberapa lampu yang tidak dimatikan dibiarkan hidup hingga menjelang malam dan tidak mematikan AC jika ruangan tidak digunakan. Sehingga perlu merekomendasikan untuk penghematan penggunaan energi. Rekomendasi yang diberikan diarahkan kepada penjadwalan jam operasi AC dan pencahayaan yaitu mematikan AC jika ruangan tidak digunakan, mengatur suhu dalam ruangan, memastikan tidak adanya udara luar yang masuk ke dalam ruangan ber-AC yang mengakibatkan efek pendingin berkurang, melakuan perawatan berkala, menggunakan jenis kaca tertentu yang dapat mengurangi panas matahari yang masuk kedalam ruangan namun tidak mengurangi pencahayaan alami, mematikan lampu penerangan jika ruangan tidak dipergunakan, menggunakan lampu penerangan hemat energi dan memanfaatkan cahaya alami pada siang hari dengan membuka tirai jendela, menggunakan saklar otomatis dengan menggunakan sensor pada bagian lampu hias gerbang depan dan lampu hias dibagian depan halaman.

\section{Kesimpulan}

Berdasarkan hasil penelitian dan pembahasan yang dilakukan pada Terminal Tipe A Antar Lintas Batas Negara Sei. Ambawang, maka ditarik kesimpulan sebagai berikut:

1. Setelah Dilakukan penelitian di Terminal Tipe A Antar Lintas Batas Negara Sei. Ambawang bahwa penggunaan energi listrik terbesar dari beban AC sekitar $54 \%$ dari beban total gabungan dan jika dilihat dari beban per-lantai diperoleh penggunaan listrik terbesar pada lantai I sekitar 73,8\% dari beban total gabungan. Sedangkan pada beban lantai I diperoleh penggunaan listrik terbesar masih pada penggunaan AC sekitar 47,2\% dan pada beban lantai II diperoleh penggunaan AC sekitar 76,9\%.

2. Evaluasi nilai IKE yang diperoleh pada seluruh gedung yaitu $6,88 \mathrm{kWh} / \mathrm{m}^{2} /$ tahun dan pada nilai IKE tanpa lantai III $7,55 \mathrm{kWh} / \mathrm{m}^{2} /$ tahun. Pada lantai I nilai IKE $6,30 \mathrm{kWh} / \mathrm{m}^{2} /$ tahun dan pada lantai II 16,7 $\mathrm{kWh} / \mathrm{m}^{2} /$ tahun. Hasil nilai IKE pada lantai I untuk ruang ber-AC adalah $195,4 \mathrm{kWh} / \mathrm{m}^{2} /$ tahun dan pada ruang tidak ber-AC adalah $0,08 \mathrm{kWh} / \mathrm{m}^{2} /$ tahun sedangkan nilai IKE pada lantai II untuk ruang ber- 
AC adalah $26,84 \mathrm{kWh} / \mathrm{m}^{2} /$ tahun dan pada ruang tidak ber-AC adalah $1,39 \mathrm{kWh} / \mathrm{m}^{2} /$ tahun.

3. Dari Hasil perhitungan evaluasi Ike bahwa penggunaan energi pada Terminal Bus Tipe A Antar Lintas Batas Negara Sei. Ambawang masih belum melewati standar IKE yang telah ditentukan.

\section{Referensi}

[1] Agus Rianto, 2007, Audit Energi dan Analisis peluang Penghematan Konsumsi Energi: Pada Sistem pengkondisian Udara Di Hotel Santika Semarang, Skripsi, Semarang: Universitas negeri Semarang

[2] Abdurarachim Halim, Pasek, Darmawan Ari dan Sulaiman, 2002,AuditEnergi Modul 2, Energy Concervation Effisiency And Cost Saving Course. Bandung: PT. Fiqry Jaya Mandiri.

[3] ASEAN-USAID. 1992. Building Energy Conservation Project. ASEAN Lawrence Berkeley Laboratory, United States.

[4] Asnal Effendi dan Miftahul, 2016, Evaluasi Intensitas Konsusmsi Energi Listrik Melalui Audit Awal Energi Listrik Di RSJ. Prof. HB. Saanin Padang, Jurnal Teknik Elektro ITP, Vol 5, No. 2; Juli 2016. JTE - ITP ISSN No. $2252-3472$.

[5] Badan Pengkajian dan Penerapan Teknologi (BPPT) 2012. Perencanaan Efisiensi dan eleatisitas Energi. Jakarta: BPPT. ISBN 978-979-3733-57-9

[6] Peraturan Menteri Energi dan Sumber daya Manusia No 13, 2012, Penghematan Pemakaian Tenaga Listrik Pada Bangunan Pemerintah.

[9] Sanafiah Faisal, 2007, Metode Penelitian, Jakarta: PT Gramedia

[10] Shalahuddin Hasan, 2014, Pelaksanaan Efisiensi energi Di Bangunan Gedung, www.nulisbuku.com

[11] SNI 03-6196-2000 Prosedur Audit Energi Bangunan Gedung.

[12] SNI 03-6197-2000 Konservasi Energi Pada Sistem Pencahayaan.

[13] Sulistyorini, Jurnal Eltek, 2012, Vol 10 Nomor 01 April 2012 ISSN 1693-4024

[14] Sulasno, 2009, Teknik Konversi Energy Listrik Dan Sistem Pengaturan, Jogyakarta: Graha Ilmu

[15] www.Suswanto, Daman. "Karakteristik Beban Tenaga Listrik", https://daman48.files.wordpress.com (diakses tanggal 8 November 2017)

\section{Biografi}

Tabita Dwilova Wijayanti, lahir di Pontianak pada tanggal 17 September 1990. Menyelesaikan pendidikan S-1 Teknik Industri di Universitas Tanjungpura Pontianak Tahun 2013 dan S-2 Teknik Elektro di Universitas Tanjungpura Pontianak Tahun 2017. Sejak tahun 2014 bekerja sebagai PPNPN di Dinas Perhubungan Provinsi Kalimantan Barat dan pada Tahun 2017 sampai dengan sekarang bekerja sebagai PPNPN di Kementerian Perhubungan Direktorat Jenderal Perhubungan Darat Area Terminal Tipe A Antar Lintas Batas Negara Sei. Ambawang. 